EMPIRE IN RETREAT 
This page intentionally left blank 


\title{
EMPIRE IN
}

\section{RETREAT}

The Past, Present, and Future of the United States

Victor Bulmer-Thomas

\author{
Yale \\ UNIVERSITY \\ PRESS
}

New Haven \& London 
Copyright (C) 2018 by Victor Bulmer-Thomas.

All rights reserved.

This book may not be reproduced, in whole or in part, including illustrations, in any form (beyond that copying permitted by Sections 107 and 108 of the

U.S. Copyright Law and except by reviewers for the public press), without written permission from the publishers.

Yale University Press books may be purchased in quantity for educational, business, or promotional use. For information, please e-mail sales.press@yale.edu (U.S.office) or sales@yaleup.co.uk (U.K. office).

Set in Electra type by Westchester Publishing Services.

Printed in the United States of America.

Library of Congress Control Number: 2017955409

ISBN 978-0-300-21000-2 (hardcover : alk. paper)

A catalogue record for this book is available from the British Library.

This paper meets the requirements of ANSI/NISO Z39.48-1992 (Permanence of Paper).

10987654321 
For Nia and Rio 
This page intentionally left blank 